HUNGARIAN AGRICULTURAL ENGINEERING

$N^{\circ} 28 / 201530-33$

Published online: http://hae-journals.org/

HU ISSN 0864-7410 (Print) / HU ISSN 2415-9751(Online)

DOI: 10.17676/HAE.2015.28.30
PERIODICAL OF THE COMITTEE OF AGRICULTURAL AND BIOSYSTEM ENGINEERING OF THE HUNGARIAN ACADEMY OF SCIENCES and

SZENT ISTVÁN UNIVERSITY

Faculty of Mechanical Engineering

\title{
MODELLING OF A HYBRID CLIMATE SYSTEM
}

\author{
Author(s): \\ G. Bércesi ${ }^{1}-$ K. Petróczki ${ }^{1}-J$. Beke ${ }^{2}$
}

\author{
Affiliation: \\ 1Department of Metrology, Process Engineering Institute, Szent István University, Páter K. u. 1., Gödöllő, H-2103, \\ Hungary \\ 2Department of Energetics, Process Engineering Institute, Szent István University, Páter K. u. 1., Gödöllö, H-2103, \\ Hungary
}

\section{Email address:}

bercesi.gabor@hallgato.szie.hu, petroczki.karoly@gek.szie.hu, beke.janos@gek.szie.hu

\begin{abstract}
In Hungary a large part of consumed energy is spent on heating and cooling buildings. Utilization of renewable energy sources is spreading in this sector, but because of their disadvantages, they are mostly used as a part of hybrid climate systems. The paper deals with setting up a mathematical model of a hybrid climate system of an educational building, in order to examine its dynamical behaviors and research conditions of optimal operation and design principles of such systems. The building equipped with multiple types of heat sources and radiators, and to help research and education, its climate system is equipped with a high accuracy measuring system.
\end{abstract}

\section{Keywords}

hybrid climate system, modelling, heat pump

\section{Introduction}

In Hungary more than $60 \%$ of the annual energy use of buildings is spent on heating and if the climate system is supplemented with a cooling system in the summer, this ratio can increase further. This ratio is expected to persist longer. Thus special attention should be paid on saving energy - and mostly fossil fuels - on energy supply of heating, cooling and air conditioning systems of buildings. So because of increasing environmental awareness utilization of renewable energy sources is growing. However due to their disadvantages, like higher costs and limited availability, they are often used as a part of a hybrid energetic system supplemented with heat sources using fossil fuels. In stand-alone renewable energy using systems biomass firing is used most often, however in hybrid systems heat pumps with different heat sources (e.g. ground heat, groundwater, surface water, air), together with gas boilers are mostly utilized. One of the advantages of heat pump systems is that usually they can be used also for heating and cooling purposes. Caused by dependence of their performance on environmental parameters, there is an optimal range of conditions for using renewable energy sources or switch to conventional ones. There should also be an optimal capacity of heat buffer tanks in the heating system of each building using conventional and renewable energy sources together, in order to damp dynamic changes in heat energy demand on the heat source side properly in a cost effective way.
In development and optimization of a process, first step is understanding the operation and the dynamical behaviors of the system that can be done by construction of a mathematical model of the system $[1,2]$

This paper is based upon a $\mathrm{PhD}$ research. Its aim is construction and identification of the system model of building under investigation using the measurement data provided by the installed complex measuring system. Then using the model and numerical simulation methods, examination of effect of design and operational parameters on the efficiency of multiple source hybrid climate systems. This paper deals with measurement and modelling objectives of the topic.

\section{Measurement}

The experimental building with its climate system placed under investigation is situated on the Campus of Szent István University, Gödöllö, Hungary. Due to its recent renovation became a two-floor building with the Museum of the History of Agricultural Tool- and Machine Development on the basement and lecture halls, classrooms, laboratories and offices on the top floor. Its name is Knowledge Transfer Centre (TK). It has $3805 \mathrm{~m}^{2}$ area and $15880 \mathrm{~m}^{3}$ heated volume. The main part of its climate system is a ground-source water to water heat pump and 10 pcs of $100 \mathrm{~m}$ deep borehole heat exchangers. They can provide about $68 \mathrm{~kW}$ heating and $50 \mathrm{~kW}$ cooling power. As supplementary heat source in the heating season there are installed 2 pieces of $100 \mathrm{~kW}$ and 1 piece of $80 \mathrm{~kW}$ nominal power condensing gas boilers, in the cooling season a $407 \mathrm{~kW}$ water chiller (air - water heat exchanger) can be operated in the night. The lecture halls, classrooms, offices and laboratories are installed with fan-coil systems, on the corridors there are flat radiators, and the greatest lecture hall with 350 seats is completed with an air handler unit. In the heating system there is a 1000 liter capacity buffer tank. Figure 1 shows the photo of the frontage of the building and the schematic drawing of its hybrid heating system.

Within the project TÁMOP-4.2.1.B-11/2/KMR-2011-0003 project with title "Increase of the level of the education and research" together with the subproject in the Faculty of Mechanical Engineering: "Energy production based on renewable energy sources" a complex measuring system had been installed on the climate system of the building, that works independently form its own direct digital control (DDC). It operates almost 
continuously since the May of 2013. It measures temperatures on 26 points of the climate system including forward and returning temperatures of borehole heat exchangers, heat pump, fan-coil and radiator circuits, buffer tank temperature, heated room and ambient temperatures. The temperature sensors are Pt-100 RTDs connected to an Agilent 34970A type measuring amplifier. In addition the electric energy consumption of the heat pump is also measured with the same amplifier. Through a measuring computer the data collected with one minute sample period is saved and can also be viewed online. The most difficult task is measurement of flow rates because the measuring system was installed on the completed and working climate system in which the piping could not be disrupted. But we suppose the inverter driven circulating pumps of the system are operating at approximately constant flow rates, so it is not needed to measure them constantly, and we can use for example a snap-on ultrasonic flow sensor for single measurements and record only the on/off state of pumps [3]. Figure 2 shows an example data series collected by the measuring system, plotted in function of time.
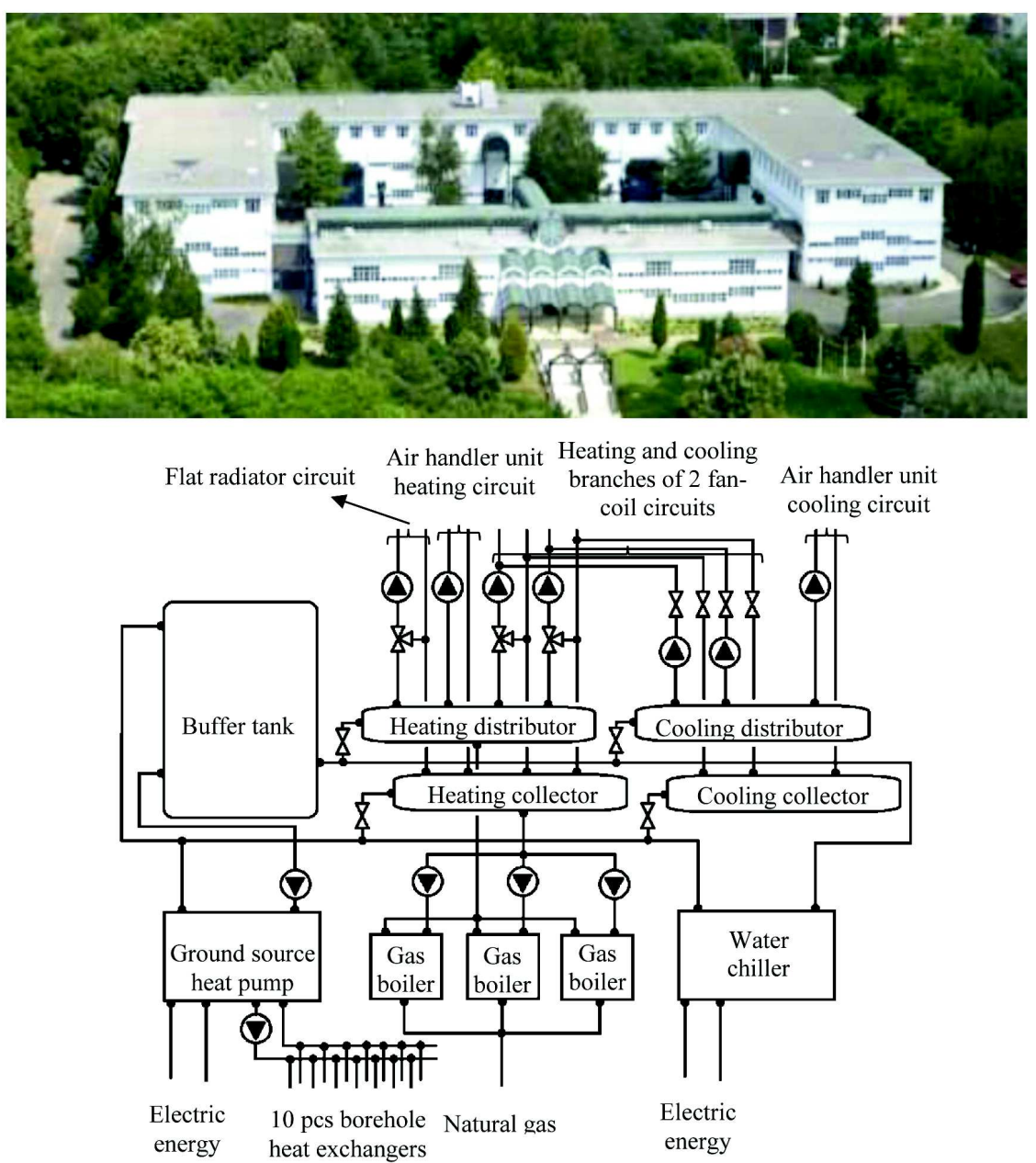

Figure 1. The frontage of the building and the schematics of its climate system

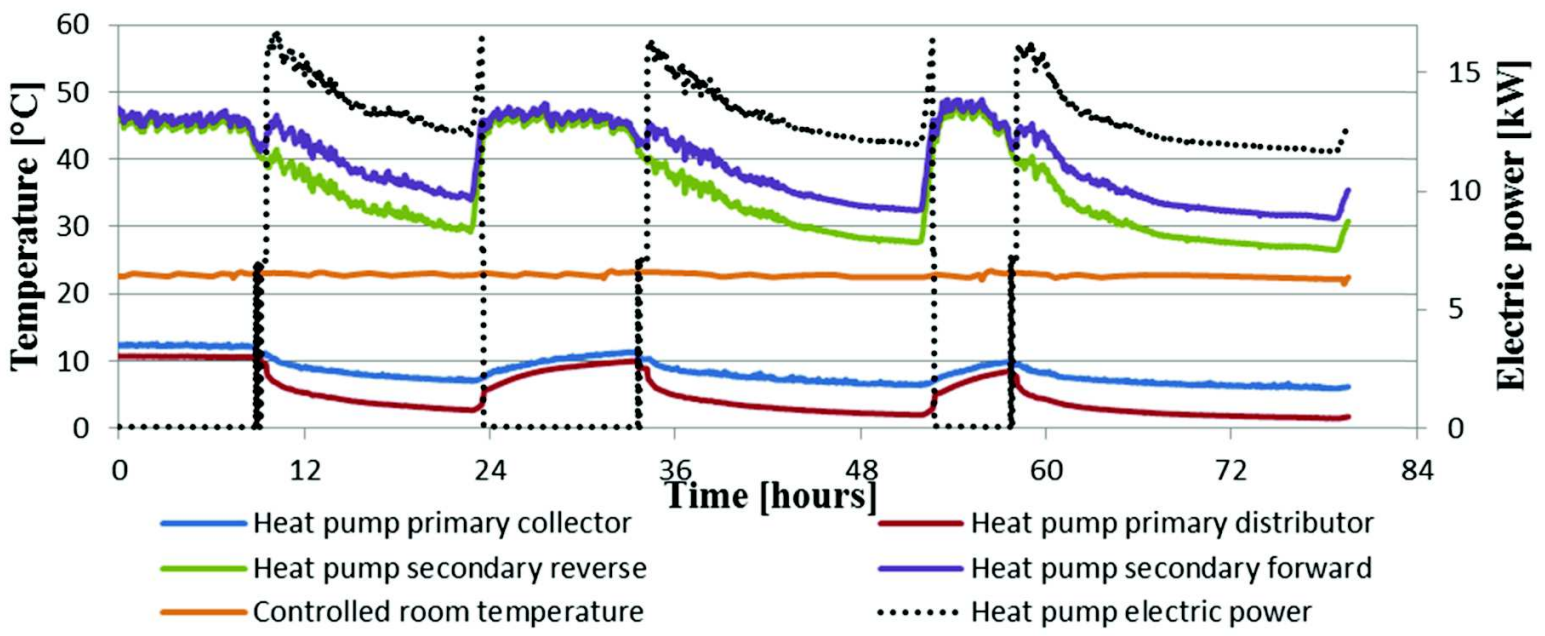

Figure 2. Example of visualization of data collected by the measuring system 


\section{Modelling}

The aim of heating/cooling/air conditioning of buildings is to set the parameters of the thermodynamical equilibrium to the desired value. Thus in modelling of the heating system the heat balance of the building should be analyzed with examination of heat losses, heat storage elements and heat sources $[4,5]$. All the factors of these processes can be identified using measurement data and characteristics of the used materials.

The energetic systems are usually distributed parameter systems. A basic model of them can be easily made with reducing to lumped element modelling using heat current network analog model. This is built from specific connection of models of each part of the system. The lumped element heat current network analog model is built from thermal resistances, heat capacitances, voltage generators representing temperature difference and current generators representing heat current (flow). The model can be used for the investigations about dynamics of the system and the heat buffer tanks. The main simplifications of the this model are approximating the ground heat source model as infinite capacity heat container (with constant temperature, but if the forward temperature falls below $0{ }^{\circ} \mathrm{C}$ - because of the freezing of the soil - they produce zero temperature difference) and the heated spaces are handled as one with no difference between fancoil, radiator and air-handler units.

An improved modelling method is directly writing down the energy balance equations for each component that results a system of ordinary differential equations. This differential equation model can be supplemented with representations of real possibilities of manipulation elements (e.g. on/off state of pumps, valve/mixer valve positions) and thereby can be used for examination of real control strategies. So in this model these possibilities of manipulation are the input parameters. The output parameters are the process values for the control, like forward and returning temperatures of fan-coil and radiator circuits. This model is also built up with connection of mathematical model of each part. In this model ground source works similarly to the heat current network model, but heated space is divided to two parts: one heated with flat radiators and another one heated with fancoils and air handler units. The equations for the heating system:

The heat from the borehole heat exchangers:

$$
\begin{gathered}
\dot{\mathrm{Q}}_{\mathrm{BHE}}=\mathrm{c}_{\mathrm{BHE}} \cdot \mathrm{m}_{\mathrm{BHE}} \cdot\left(\mathrm{T}_{\mathrm{BHEr}}-\mathrm{T}_{\mathrm{BHEf}}\right) \\
\mathrm{T}_{\mathrm{BHEr}}=\left\{\begin{array}{c}
\mathrm{T}_{\mathrm{BHEf}}+3^{\circ} \mathrm{C}, \text { if } \mathrm{T}_{\mathrm{BHEf}} \geq 0^{\circ} \mathrm{C} \\
\mathrm{T}_{\mathrm{BHEf}}, \text { if } \mathrm{T}_{\mathrm{BHEf}}<0^{\circ} \mathrm{C}
\end{array}\right.
\end{gathered}
$$

The heat pump - with heat storage:

$$
\mathrm{p}_{\mathrm{HP}} \cdot\left(\dot{\mathrm{Q}}_{\mathrm{BHE}}+\mathrm{P}_{\mathrm{e}}\right)-\mathrm{P}_{\mathrm{HP}}=\mathrm{Q}_{\mathrm{HP}}
$$

The buffer tank:

$$
\begin{gathered}
\mathrm{P}_{\mathrm{HP}}-\mathrm{P}_{\mathrm{Hd}}=\dot{\mathrm{Q}_{\mathrm{P}}} \\
\mathrm{c}_{\mathrm{w}} \cdot \mathrm{m}_{\mathrm{HP}} \cdot\left(\mathrm{P}_{\mathrm{HPf}}-\mathrm{P}_{\mathrm{P}}\right)-\mathrm{c}_{\mathrm{w}} \cdot\left(\dot{\mathrm{m}}_{\mathrm{H}}-\dot{\mathrm{m}}_{\mathrm{G}}\right) \cdot\left(\mathrm{T}_{\mathrm{P}}-\mathrm{T}_{\mathrm{Hd}}\right)=\mathrm{c}_{\mathrm{w}} \cdot \mathrm{m}_{\mathrm{P}} \cdot \frac{\mathrm{dT} \mathrm{P}}{\mathrm{dt}} \\
\dot{\mathrm{m}}_{\mathrm{H}}=\mathrm{s}_{\mathrm{R}} \cdot \dot{\mathrm{m}}_{\mathrm{R}}+\mathrm{s}_{\mathrm{FC} 1} \cdot \mathrm{m}_{\mathrm{FC} 1}+\mathrm{s}_{\mathrm{FC} 2} \cdot \mathrm{m}_{\mathrm{FC} 2}
\end{gathered}
$$

The heating distributor and collector:

$$
\begin{gathered}
\mathrm{P}_{\mathrm{HP}}+\varphi_{\mathrm{G}} \cdot \mathrm{P}_{\mathrm{G}}=\mathrm{s}_{\mathrm{R}} \cdot \mathrm{P}_{\mathrm{R}}+\mathrm{s}_{\mathrm{FC} 1} \cdot \mathrm{P}_{\mathrm{FC} 1}+\mathrm{s}_{\mathrm{FC} 2} \cdot \mathrm{P}_{\mathrm{FC} 2}+ \\
+\mathrm{s}_{\mathrm{AHU}} \cdot \mathrm{P}_{\mathrm{AHU}}=\mathrm{c}_{\mathrm{w}} \cdot \mathrm{m}_{\mathrm{H}} \cdot\left(\mathrm{T}_{\mathrm{Hd}}-\mathrm{T}_{\mathrm{HC}}\right)
\end{gathered}
$$

Corridors (spaces heated with flat radiators):

$$
s_{R} \cdot P_{R}-P_{R-e}=\dot{Q_{R}}
$$

$$
\begin{aligned}
& \mathrm{s}_{\mathrm{R}} \cdot \mathrm{c}_{\mathrm{w}} \cdot \mathrm{m}_{\mathrm{R}} \cdot\left[\varphi_{\mathrm{R}} \cdot\left(\mathrm{T}_{\mathrm{Hd}}-\mathrm{T}_{\mathrm{Rr}}\right)+\mathrm{T}_{\mathrm{Rr}}\right]- \\
& -\kappa_{\mathrm{R}} \cdot \mathrm{A}_{\mathrm{R}} \cdot\left(\mathrm{T}_{\mathrm{R}}-\mathrm{T}_{\mathrm{a}}\right)=\mathrm{c}_{\mathrm{R}} \cdot \mathrm{m}_{\mathrm{R}} \cdot \frac{\mathrm{dT}_{\mathrm{R}}}{\mathrm{dt}}
\end{aligned}
$$

Spaces heated with fan-coils and air handler unit:

$$
\begin{gathered}
\mathrm{e}_{\mathrm{FC} 1} \cdot \mathrm{P}_{\mathrm{FC} 1}+\mathrm{e}_{\mathrm{FC} 2} \cdot \mathrm{P}_{\mathrm{FC} 2}+\mathrm{s}_{\mathrm{AHU}} \cdot \mathrm{P}_{\mathrm{AHU}}-\mathrm{P}_{\mathrm{FC}-\mathrm{a}}=\mathrm{Q}_{\mathrm{FC}}^{\cdot} \\
\mathrm{e}_{\mathrm{FC} 1} \cdot \mathrm{c}_{\mathrm{w}} \cdot \mathrm{m}_{\mathrm{FC} 1} \cdot\left[\varphi_{\mathrm{FC} 1} \cdot\left(\mathrm{T}_{\mathrm{Hd}}-\mathrm{T}_{\mathrm{FC} 1 \mathrm{r}}\right)+\mathrm{T}_{\mathrm{FC} 1 \mathrm{r}}\right]+ \\
+\mathrm{e}_{\mathrm{FC} 2} \cdot \mathrm{c}_{\mathrm{w}} \cdot \mathrm{m}_{\mathrm{FC} 2} \cdot\left[\varphi_{\mathrm{FC} 2} \cdot\left(\mathrm{T}_{\mathrm{Hd}}-\mathrm{T}_{\mathrm{FC} 2 \mathrm{r}}\right)+\mathrm{T}_{\mathrm{FC} 2 \mathrm{r}}\right]+ \\
\quad+\mathrm{s}_{\mathrm{AHU}} \cdot \mathrm{c}_{\mathrm{w}} \cdot \mathrm{m}_{\mathrm{AHU}} \cdot\left(\mathrm{T}_{\mathrm{Hd}}-\mathrm{T}_{\mathrm{AHUr}}\right)- \\
-\mathrm{\kappa}_{\mathrm{FC}} \cdot \mathrm{A}_{\mathrm{FC}} \cdot\left(\mathrm{T}_{\mathrm{FC}}-\mathrm{T}_{\mathrm{a}}\right)=\mathrm{c}_{\mathrm{FC}} \cdot \mathrm{m}_{\mathrm{FC}} \cdot \frac{\mathrm{dT}_{\mathrm{FC}}}{\mathrm{dt}}
\end{gathered}
$$

The conditions are, the DDC unit - according to the heat demand depending on difference between ambient and desired internal temperatures - controls valves and pumps of the radiator, fan coil and AHU circuits and operates heat sources defining temperature relation. On this basis a block diagram can be built up for numerical solution of the system of equations and running simulations with varying parameters.

\section{Conclusion}

Due to the complex data acquisition network installed on the examined hybrid climate system, the data important in terms of its operation and modelling is collected continuously. The mathematical model of the system has been constructed, which can be identified based upon the measurement data, the design parameters and knowing of actually operating controller system. Then it can be numerically simulated in order to analyze control strategies. If necessary for investigations, additional further goals can be clarification of model of the borehole heat exchangers, the heat pump and the heated spaces and their relations.

\section{Nomenclature}

$\mathrm{P}$ power W

$\mathrm{T}$ temperature $\mathrm{K}$

$\mathrm{m}$ mass $\mathrm{kg}$

$\mathrm{t}$ time $\mathrm{s}$

$\mathrm{m}$. mass flow $\mathrm{kg} \cdot \mathrm{s}^{-1}$

c specific heat $\quad \mathrm{J} \cdot \mathrm{kg}^{-1} \cdot \mathrm{K}^{-1}$

$\kappa$ heat conductivity $\mathrm{W} \cdot \mathrm{m}^{-2} \cdot \mathrm{K}^{-1}$

A surface area $\mathrm{m}^{2}$

pHP heat pump power level $\quad 0 \%, 50 \%, 100 \%$

s state of circulating pump $\quad 0$ - off, $1-$ on

e state of shut off valve $\quad 0$ - close, $1-$ open

$\varphi \quad$ position of mixing valves $\quad 0-100 \%$

$\varphi \mathrm{G} \quad$ power level of gas boilers $\quad 0-100 \%$

\section{Subscripts}

BHE borehole heat exchanger

HP heat pump

$\mathrm{H}$ heating

P buffer tank

$\mathrm{R} \quad$ radiator circuit

FC1,2 fan-coil and air handling unit circuit

AHU air handling unit circuit

w water

$r \quad$ returning

f forward

d distributor

c collector

ambient 


\section{References}

[1] Caraman S., Barbu M., Minzu V., Badea N. Ceanga E.: 2010. Modelling and control of an autonomous energetic system obtained through trigeneration, Bul. Inst. Polit. Iaşi, 56-60 (4), pp. 61-72.

[2] Cho H., Luck R., Eksioglu S. D., Chamra L. M.: 2009. Cost-optimized real-time operation of CHP systems, Energy and Buildings, 41(4), pp. 445-451.

http://dx.doi.org/10.1016/j.enbuild.2008.11.011
[3] Gergely Z., Tóth L., Petróczki K., Bércesi G.: 2013 Renewable energy assisted air conditioning system instrumentation, Hungarian Agricultural Engineering, 25/2013, pp. 13 - 16

[4] Hámori S.: 2008. Épületgépészeti irányítástechnika, Debreceni Egyetem, 119 p.

[5] van Schijndel A. W. M., de Wit M. H.: 2003. Advanced simulation of building systems and control with simulink. Eindhoven, Netherlands, Eighth Inernational IBPSA Conference, University of Technology, Eindhoven, pp. 1185 - 1192. 